図譜

\title{
Candida granuloma
}

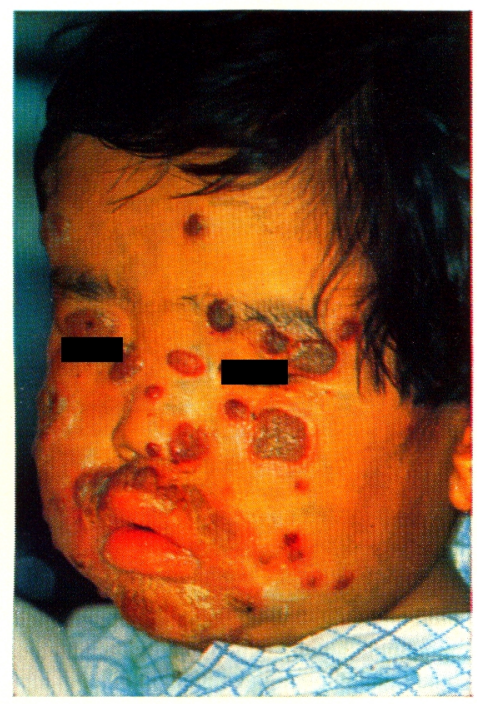

因 1.初䟻時所見

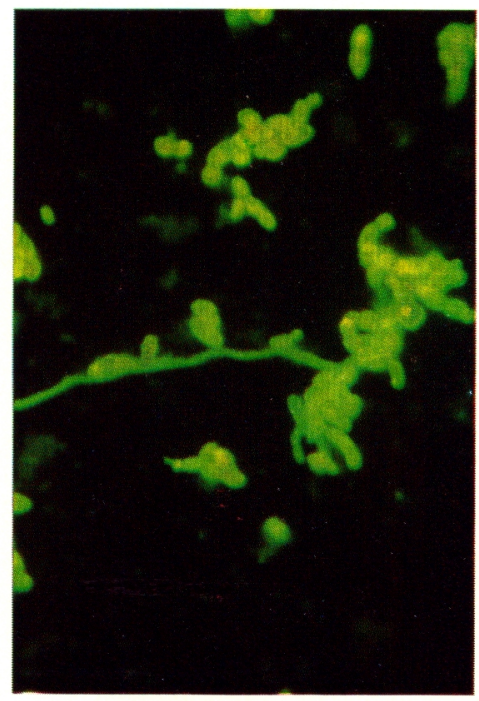

网 2、慗光乱体法による患者血清抗体の測定 (自家株 128倍)

\section{患者 1 才11力月, 男坚。

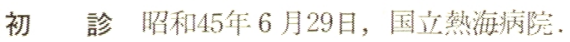

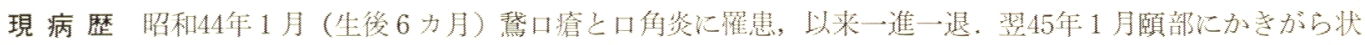

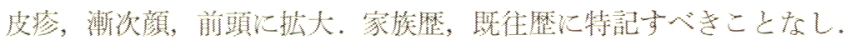

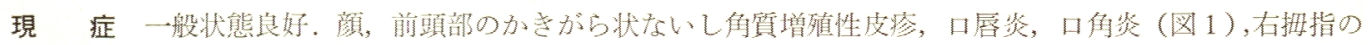

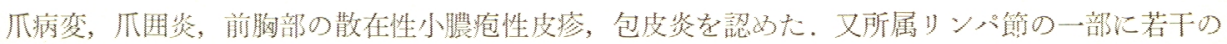

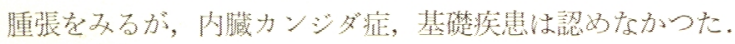

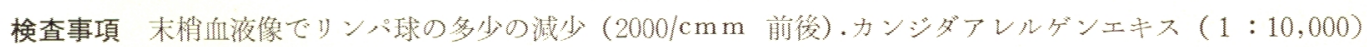

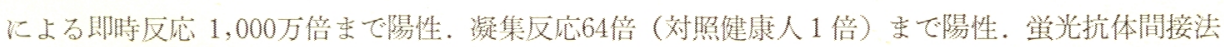

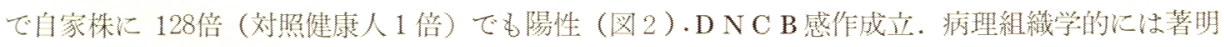

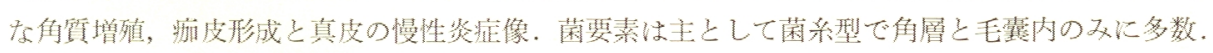

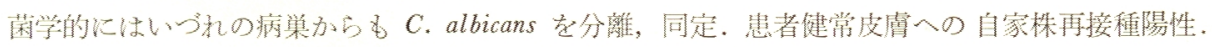

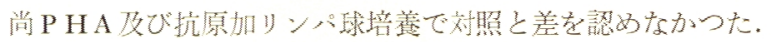

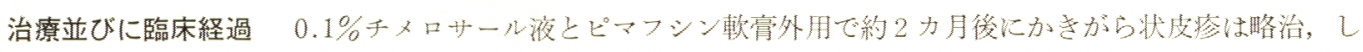

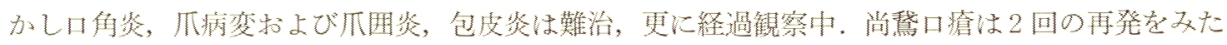

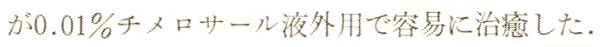

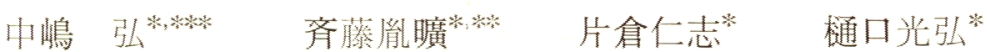

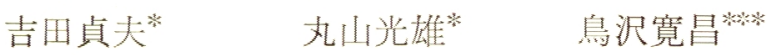

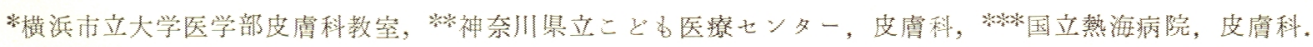

